\title{
Het brein als heer en knecht van genees- en genotmiddelen
}

Citation for published version (APA):

Riedel, W. J. (2004). Het brein als heer en knecht van genees- en genotmiddelen. Universiteit Maastricht. https://doi.org/10.26481/spe.20040618wr

Document status and date:

Published: 18/06/2004

DOI:

10.26481/spe.20040618wr

Document Version:

Publisher's PDF, also known as Version of record

\section{Please check the document version of this publication:}

- A submitted manuscript is the version of the article upon submission and before peer-review. There can be important differences between the submitted version and the official published version of record.

People interested in the research are advised to contact the author for the final version of the publication, or visit the DOI to the publisher's website.

- The final author version and the galley proof are versions of the publication after peer review.

- The final published version features the final layout of the paper including the volume, issue and page numbers.

Link to publication

\footnotetext{
General rights rights.

- You may freely distribute the URL identifying the publication in the public portal. please follow below link for the End User Agreement:

www.umlib.nl/taverne-license

Take down policy

If you believe that this document breaches copyright please contact us at:

repository@maastrichtuniversity.nl

providing details and we will investigate your claim.
}

Copyright and moral rights for the publications made accessible in the public portal are retained by the authors and/or other copyright owners and it is a condition of accessing publications that users recognise and abide by the legal requirements associated with these

- Users may download and print one copy of any publication from the public portal for the purpose of private study or research.

- You may not further distribute the material or use it for any profit-making activity or commercial gain

If the publication is distributed under the terms of Article $25 \mathrm{fa}$ of the Dutch Copyright Act, indicated by the "Taverne" license above, 
Het brein als heer en knecht van genees- en genotmiddelen 


\section{Colofon}

Basisontwerp en realisatie: Unigraphic, Universiteit Maostricht.

ISBN 90-5681-202-5

NUR 770

Alle rechten voorbehouden. Niets uit deze uitgove mag worden verveelvoudigd, opgeslagen in een geautomatiseerd gegevensbestand of openbaar gemaakt, zonder voorafgaande schriftelijke toestemming van de auteur of uitgever. 


\section{$m G$ VAC 553}

\section{Het brein als heer en knecht van genees- en genotmiddelen}

\section{Oratie}

Rede uitgesproken bij de aanvaarding van het bijzonder hoogleraarschap Experimentele Psychofarmacologie aan de Universiteit Maastricht.

Op vrijdag 18 juni 2004

Door

Dr. W.J. Riedel 


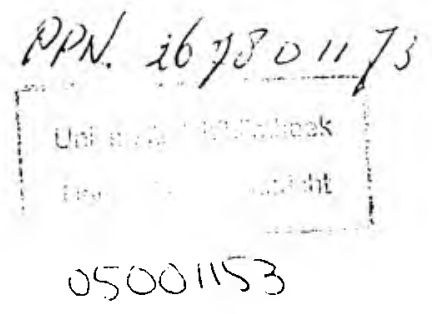




\title{
Het brein als heer en knecht van genees- en genotmiddelen
}

\author{
Mijnheer de Rector Magnificus, \\ Zeer gewaardeerde toehoorders,
}

Psychofarmacologie wordt wel omschreven als de leer van de effecten van psychoactieve stoffen (medicijnen of drugs; geneesmiddelen of genotmiddelen) die gedrag of psychologische processen (zoals denken, aandacht en geheugen) beïnvloeden door iets in de chemie van de hersenen te veranderen. De oudst bekende psychoactieve stof is waarschijnlijk de vliegenzwam sinds ongeveer 10000 voor $\mathrm{Chr}$.

Deze paddestoel bevat oa. muscarine wat in de hersenen aan receptoren van dezelfde naam bindt. De voornaamste gevolgen van inname waren hallucinaties, manie en meer in het algemeen gesteld: gekte. De geestelijke gezondheid zal er, 10000 voor Christus, waarschijnlijk niet mee gediend zijn geweest. Maar vliegenzwam-geïnduceerde manie zal daarmee, weliswaar per ongeluk, het eerste experimenteel psychofarmacologische humane model van een psychiatrische ziekte geweest kunnen zijn.

Het gebruik van psychoactieve stoffen om geestelijke gezondheid te bevorderen, of op zn minst afwijkend gedrag te verminderen, is echter nog maar iets meer dan 50 jaar oud. Dat werd met name bevorderd door de ontdekking van neurotransmitters zoals serotonine maar ook door de synthese van nieuwe stoffen die bekend werden als tranquillizers en antidepressiva (1).

In 1975 publiceerde Piet Vroon zijn boek 'Bewustzijn, Hersenen \& Gedrag', 'het individu in zijn dubbelrol als heer en knecht van zichzelf' (2).

Vroon bedoelde daarmee dat het menselijke centraal zenuwstelsel niet als een simpel orgaan te beschrijven is en eigenlijk afhankelijk van de situatie, 2 totaal tegengestelde rollen aan kan nemen. De knecht-rol slaat op het feit dat de mens knecht of slaaf is van fysiologische processen, waaraan hij of zij op een wetmatige manier onderworpen is. Dit kan bijvoorbeeld gelden voor primitieve emoties zoals angst en vreugde, maar ook voor schijnbaar automatisch verlopende denk- en handelingsprocessen. 
De heer-rol slaat op het feit dat de mens tegelijkertijd baas is over de eigen fysiologische processen en emoties en de daarbij behorende fysiologische toestanden tot op zeker hoogte kan kiezen.

Vroon wees op deze tegenstelling omdat die van belang is voor het verklaren van het moeilijk te vatten begrip bewustzijn ten opzichte van het waarneembare menselijke gedrag en de biologische basis daarvan in de hersenen.

\section{Experimentele Psychofarmacologie}

De in ons moderne taalgebruik meest genoemde psychoactieve stof is waarschijnlijk wel adrenaline. Ik geef enkele willekeurige voorbeelden van uitspraken over adrenaline die ik in de afgelopen tijd op internet heb aangetroffen.

We lezen: "Kent $u$ dat gevoel wanneer $U$ op het punt staat iets radicaals te doen? De adrenaline raast door je aderen als een op hol geslagen paard. Alle zintuigen staan op scherp en je bent uiterst alert. Je hart slaat met meer slagen per minuut dan de snelste house-plaat en dan doe je het.... Of toch niet"

We lezen: "Wetenschap is ook thrill-seeking...." "Dat adrenaline-moment van iets ontdekken, iets vinden wat nog niemand had gezien is geweldig...." "Bij vertrek uit de bibliotheek had ik daarna nog een serie adrenalinemomenten toen ik achtereenvolgens mijn rijbewijs, de sleutel van mijn kluisje, en tweemaal mijn portemonnee kwijt was"

We lezen: "Van de adrenaline minuten later nog niet 112 kunnen bellen"

Achtereenvolgens lezen we verschillende interpretaties van de psychische toestand die kerinelijk bij adrenaline hoort:

1) zintuiglijke functies en alertheid functioneren maximaal

2) opwinding en een goed gevoel

3) schrik en niet zo'n goed gevoel

4) niet kunnen handelen

Aardig is dat alle citaten parafrases zijn van bevindingen uit experimenteel onderzoek. Er zijn ongetwijfeld nog meer voorbeelden te vinden. Een van de bekendste is dat adrenaline mensen 'trigger-happy' maakt, tot 
handelen aanzet voordat ze nadenken. De vraag is natuurlijk of de interpretaties van de verschillende schrijvers strijdig zijn of niet. Dat lijken ze natuurlijk op het eerste gezicht wel. Feit is dat adrenaline een lichaamseigen stof is die door de bijnieren wordt afgegeven en zowel in het perifere zenuwstelsel als in het centrale zenuwstelsel als boodschapperstof of neurotransmitter kan fungeren. Adrenaline kan inderdaad als gevolg van psychologische processen zoals opwinding, angst, agressie of vreugde worden vrijgegeven. Vervolgens beïnvloedt dat dan weer het gedrag. Maar is adrenaline nu oorzaak of juist gevolg van gedrag?

Een van de beste voorbeelden van een experiment waarin dit uitgezocht werd, is misschien wel het klassieke experiment van Schachter \& Singer uit $1962(3)$.

Vijfenzeventig gezonde proefpersonen kregen een injectie met adrenaline toegediend en werden in 3 groepen verdeeld. Er was ook nog een ongeveer even grote placebo-groep. Alle proefpersonen werden verteld dat zij suproxine, een vitamine-supplement kregen toegediend wat hun gezichtsvermogen zou kunnen verbeteren. De eerste groep werd juist geinformeerd over de werkingen en bijwerkingen. Dit hield in dat zij voorbereid waren op de fysiologisch waarneembare gevolgen van adrenaline-toediening: de voornaamste daarvan zijn versnelling van hartslag en ademhaling en bloeddrukverhoging. Een tweede groep werd verkeerd geïformeerd om te controleren voor suggestie, zij werden verteld dat de bijwerkingen bestaan uit tintelende voeten, jeuk en hoofdpijn. Dit zijn geen bijwerkingen van adrenaline. De derde groep werd helemaal niet geïformeerd over mogelijke bijwerkingen. Alle proefpersonen werden 20 minuten in een wachtkamer gezet, met de vraag om enkele vragenlijsten in te vullen en om te wachten totdat de injectie ging werken. Zij werden daar geconfronteerd met een nep-proefpersoon, die in werkelijkheid een lid van het onderzoeksteam was. Bij de helft van de proefpersonen gedroeg de nep-proefpersoon zich eufoor en nodigde de echte proefpersonen uit om mee te doen, door bijvoorbeeld vliegtuigjes te vouwen van de vragenlijsten en deze vervolgens onder veel jolijt te lanceren. $B i j$ de andere helft van de proefpersonen gedroeg de nep-proefpersoon zich boos en verbaal agressief door bijvoorbeeld openlijk zijn minachting over de kwaliteit van de vragenlijsten en het hele onderzoek uit te spreken.

De resultaten lieten zien dat alleen proefpersonen die met een adrenaline-injectie waren behandeld en die niet juist geïnformeerd waren zich 
lieten beïnvloeden door de nep-proefpersoon. Het effect van een adrenaline-injectie hing dus inderdaad af van de informatie die erover gegeven was.

Schachter and Singer concludeerden dat om emotie te ervaren en ook te uiten aan twee voorwaarden voldaan moet zijn, $\mathrm{nl}$. fysiologische activatie en een verwachting over wat de daarbij behorende symptomen veroorzaakt.

Wanneer mensen opgewonden zijn, door bijvoorbeeld adrenaline, en de oorzaak niet weten, wordt een reden gezocht. De emotionele toon van de omgeving, eufoor of agressief, kan dan kritiekloos worden overgenomen. Wanneer mensen weten dat zij geïnjecteerd zijn met adrenaline, hebben zij al een verklaring voor de bij zichzelf waargenomen fysiologische verschijnselen en zetten deze signalen dan niet in actie om wanneer de omgeving daartoe uitnodigt.

Wanneer iemand in de omgeving emotie waarneemt, maar zelf geen activatie voelt, wordt de emotie niet overgenomen.

Er is op het Schachter \& Singer experiment misschien wel het een en ander aan te merken, het is bijvoorbeeld nooit meer exact gerepliceerd, maar ik vind dit experiment model staan voor een 2-richtingen opvatting van experimentele psychofarmacologie. Daarin is sprake van een gecontroleerd experiment waarbij onafhankelijke variabelen zowel farmacologisch als psychologisch van aard zijn, te weten respectievelijk adrenalinetoediening als farmacologische manipulatie en de informatie daarover en de confrontatie met het gedrag van de nep-proefpersoon als psychologische manipulaties. De afhankelijke variabele kan bestaan uit waarneembaar gedrag, zelfgerapporteerde gevoelens, of uit fysiologische reacties.

Adrenaline is zowel een lichaamseigen stof als een psychofarmacon. Adrenaline-afgifte kan dus worden bestudeerd als functie van gedrag, maar ook kan gedrag juist als functie van de toediening van adrenaline worden bestudeerd.

Terminologisch heeft dat belangrijke gevolgen. Bij het eerste voorbeeld waar we veronderstellen dat de psyche veroorzakend is en de afgifte van een farmacologisch werkzame stof gevolg, past eigenlijk alleen de term Psychofarmacologie. Bij het tweede voorbeeld veronderstellen we dat de toediening van een farmacologische stof veroorzaker is van veranderingen in de psyche, ofwel gedachten, emoties en gedrag. Symbolisch kunnen we dit ook beschrijven als de tegenstelling tussen top-down en bottom-up processen. 
Wat betekent dit nu voor de psychofarmacologie? Ten eerste moeten we nog even stilstaan bij een modern fenomeen: de geformaliseerde ethische toetsing. Dit is niet het moment om te gaan speculeren over welke ethische commissie een replicatie van het Schachter Singer experiment anno 2004 nog zou gaan goedkeuren, die kans lijkt me klein, maar een ander aspect van de geformaliseerde ethische code die tegenwoordig gangbaar is, valt direct op: De over de middelen verstrekte informatie kan, onder bepaalde omstandigheden, de uitkomsten mede beinvloeden. ledere proefpersoon of patiënt die aan een onderzoek deelneemt dient zo accuraat en begrijpelijk mogelijk te worden geïnformeerd over de werkingen en bijwerkingen van experimenteel toegediende middelen. Maar eigenlijk zouden ze ook geïnformeerd moeten worden over de vele bijwerkingen die optreden na toediening van een placebo, of over het effect van informeren zelf: $\mathrm{nl}$. dat bijwerkingen juist meer of minder optreden al naar gelang er meer of gerichter geinformeerd wordt. Maar hoe doe je dat? Dat is wellicht een onderwerp voor toekomstig onderzoek.

In de tweede plaats geldt dat altijd goede, objectieve en gestandaardiseerde methodieken gebruikt dienen te worden.

We hebben zojuist de termen psychofarmacologie en farmacopsychologie geïntroduceerd. De meeste van onze onderzoeken zijn volgens deze terminologie farmacopsychologisch van aard. De onafhankelijke variabele bestaat uit het toedienen van een of meer doseringen van een of meer stoffen, terwijl prestatie op een cognitieve test of een ander gedragsaspect als afhankelijke variabele fungeert.

De term Farmacopsychologie is echter nooit in de mode geraakt en de weerbarstige onderzoekspraktijk laat zien dat eigenlijk alleen maar van psychofarmacologie wordt gesproken. Binnen de psychologie, zoveel is wel duidelijk, hoort dit gebied thuis bij de biologische psychologie en de neuropsychologie of neurocognitie. Maar het leunt ook sterk aan tegen de Biologische Psychiatrie. (en daarover gaat het volgende onderzoeksvoorbeeld)

\section{Onderzoek}

Ik geef een voorbeeld dat gaat over het gebruik van farmaca als diagnosticum om de werking van fysiologische en psychologische functies te onderzoeken. Dit worden ook wel provocatietests genoemd. Met name Professor van Praag was een voorvechter van deze methodiek en hij heeft ervoor gezorgd dat deze momenteel op diverse plekken in Maastricht veelvuldig wordt toegepast (4). Ik zal betogen dat deze methode niet alleen van nut is als diagnosticum in de Psychiatrie maar ook uitstekend 
past bij het fundamenteel onderzoek naar cognitieve en andere psychologische functies.

Het voorbeeld wat ik kies gaat over de vergelijking van depressieve patiënten en gezonde proefpersonen op een aantal psychologische en fysiologische functies. De primaire vraagstelling van dit type onderzoek was of de regeling door serotonine van de afgifte van het bijnierhormoon cortisol verstoord was (5).

Waar hier eigenlijk gebruik van gemaakt wordt is dat de anatomische banen die hierin een rol spelen, nagenoeg volledig bekend zijn. We geven de patiënten en proefpersonen specifieke serotonine-agonisten: dat zijn stoffen die de rol van serotonine nabootsen. Ze doen dat in dit geval ook nog op verschillende receptoren, $n l$. de $1 A$ en de $2 C$ receptoren. We bekijken vervolgens iedere 30 minuten de hoeveelheid uitgescheiden cortisol. We gaan er daarbij vanuit dat de serotonine agonisten binden aan receptoren op de hypothalamus, een kern ergens in de lagere hersenen. Van daaruit wordt een signaal doorgegeven aan de hypofyse en vandaaruit wederom een signaal naar de bijnier waar cortisol wordt afgegeven. Hoe meer prikkeling door serotonine-agonisten, hoe meer cortisol er wordt afgegeven. De afgifte van cortisol over een bepaalde tijd, weerspiegelt dan de serotonerge functie van patiënt of proefpersoon.

Beide stoffen veroorzaken bij gezonde proefpersonen een normale kortdurende cortisol verhoging. Maar bij de patiëntengroep is duidelijk een verminderde reactie op één van de 2 stoffen te zien.

Maar wanneer we bijvoorbeeld kijken naar hoe de patiënten subjectief reageren op deze stoffen, dan zien we iets totaal anders. De mate van ervaren somberheid is uiteraard groter bij patienten maar neemt zelfs nog kortdurend toe wanneer ze aan de andere stof worden blootgesteld. Gezonde proefpersonen merken helemaal niks zoals in de onderste lijntjes te zien is.

Bij de effecten op het geheugen zit het weer anders: het onthouden van woordén gaat na beide stoffen een stuk slechter bij gezonde proefpersonen terwijl het geheugen van patiënten eerder lijkt te verbeteren.

En bij de effecten op reactietijd lijken beide groepen min of meer gelijk op de stoffen te reageren: een van de 2 stoffen vertraagt de reactietijd, bij beide groepen. 
Wat is nu de moraal? Wanneer het serotonine systeem gestimuleerd wordt kun je niet één, maar wel vier of vijf onafhankelijke door serotonine geregelde functies doormeten (6). En deze kunnen afhankelijk van het soort stof en de patiëntengroep verschillend geregeld en ontregeld zijn.

Deze methode maakt diagnostiek mogelijk die hopelijk leidt tot nauwkeurige voorspellingen over welke stoffen waar in de hersenen voor welk soort aandoening geschikt zijn. Daarnaast moet worden gezegd dat veel meer fundamenteel onderzoek nodig is om uit te zoeken welke functies waar in de hersenen geregeld worden en met welke stoffen dit getoond kan worden. Ook hier geldt dat de interpretatie van resultaten alleen mogelijk is door het vergelijken van bottom-up invloeden van farmaca op gedrag met de top-down invloeden op gedrag en fysiologie van veranderde receptor-gevoeligheid bij patienten en de daarmee samenhangende veranderde werking van de farmaca.

Verder laat deze methode zich uitstekend combineren met moderne beeldvormende 'neuroimaging' technieken zoals EEG, PET receptor-binding en functionele MRI.

\section{Historisch Perspectief}

$\cup$ kent waarschijnlijk wel de gele sticker op de verpakking van geneesmiddelen. Die bevat de waarschuwing dat een geneesmiddel de rijvaardigheid kan beinvloeden en gebiedt tot voorzichtigheid. Ik kwam in 1986 naar Maastricht om dat soort onderzoek te doen. Hoe kwam dat eigenlijk?

Vijfentwintig jaar geleden, van 1979 tot 1981 was ik als student, lid van het dagelijks bestuur en het vakgroepsbestuur van de vakgroep Functieleer aan de subfaculteit Psychologie van de Rijksuniversiteit Groningen. Dat betekende resp. $1 x$ in de week en $1 x$ in de 2 weken vergaderen. Ik kan me van die periode nog maar 2 concrete besluiten goed herinneren. Hopelijk is het niet representatief voor mijn geheugen tijdens mijn studie. Een van die 2 besluiten die ik mij nog goed herinner was dat er een Amerikaan, een zekere Jim O'Hanlon, benoemd zou gaan worden tot gasthoogleraar in biologische aspecten van verkeersgedrag. De verkeerskunde was toen een snel groeiende werkgroep binnen de vakgroep functieleer. Het bijzondere aan die Amerikaan was dat hij veel geld nodig had en liefst ook nog per direct, om een auto met meetapparatuur op te tuigen om de invloed van geneesmiddelen en drugs op rijvaardigheid op de openbare weg te meten en daarover moesten we 
een beslissing nemen. $\mathrm{k}$ twijfelde nog even of dat wel verstandig was en stemde toen voor.

In 1982 verscheen de eerste publicatie van O'Hanlon in Science over dit voor die tijd baanbrekend onderzoek (7). In de eerste plaats omdat het éen van de eerste onderzoeken in z'n soort was, nl. het op de openbare weg meten van de invloed van geneesmiddelen op rijvaardigheid, waarbij dan ook nog gebruik gemaakt werd van een volledig geautomatiseerd meetsysteem. Ten tweede was het in die tijd zeker geen algemeen geaccepteerd feit dat een therapeutische dosering van $10 \mathrm{mg}$ van het kalmeringsmiddel diazepam (Valium") sederend of aandachtsverslappend was en daardoor de rijvaardigheid kon verminderen en dus een bedreiging vormde voor de verkeersveiligheid.

Maar in Utrecht was er ook al iemand op hetzelfde idee gekomen, $\mathrm{nl}$. Dr. Johan de Gier (thans Hoogleraar in Groningen), die in 1980 promoveerde op het proefschrift Geneesmiddelen en Verkeersveiligheid (8). Hij deed soortgelijke proeven op de openbare weg onder invloed van geneesmiddelen, ook met middelen zoals Valium", en zijn meetinstrument bestond kort samengevat uit een beoordeling door een examinator van de ANWB (9).

In 1986 begonnen O'Hanlon \& De Gier in Maastricht aan de toenmalige Rijksuniversiteit Limburg het Instituut voor Geneesmiddelen, Veiligheid en Gedrag.

Ondertussen gingen de achterblijvende medewerkers in Groningen door met het onderzoek en één van de twee, begon zelfs een identiek project in Utrecht. Toen was dus de unieke situatie ontstaan dat er vanuit 3 verschillende Universiteiten, $\mathrm{nl}$. Groningen, Utrecht en Maastricht, geïnstrumenteerde auto's met gedrogeerde proefpersonen in Nederland rondreden. Nog unieker was dat Nederland het enige land ter wereld was waar dit onderzoek op de openbare weg gebeurde.

Vernieuwend aan deze geïnstrumenteerde onderzoeksauto was indertijd dat het "gecontroleerd veldonderzoek betrof. Het besturen van een auto is een van de dagelijkse gedragingen die routinematig veel plaatsvindt en die binnen zekere grenzen volgens voorspelbare en dus meetbare regels verloopt. De meest simpele vorm van rijgedrag bestaat domweg uit het koershouden tussen de witte lijnen. 
Dat rechtrijden relatief eenvoudig meetbaar is blijkt wanneer continu de positie van de auto op de weg bepaald wordt en geïntegreerd wordt over de tijd tot een soort slingerindex. Overigens is de auto niet alleen geïnstrumenteerd als meetauto, maar ook met dubbele bediening en altijd bemand door een ervaren en gediplomeerd rijinstructeur als veiligheidssupervisor. Een van de effecten van rijden onder invloed is dat de bestuurder gaat slingeren. Dat is met deze methode dus in een enkel getal uit te drukken. Ter ijking en vergelijking van dit principe, is de invloed van alcohol op rijgedrag ooit op een afgesloten weg in de provincie Groningen met deze methode bepaald.

Omdat de prestatieverminderende invloed van alcohol op rijgedrag met een dosis-response curve geijkt is, wordt deze als referentie gebruikt bij het laten zien van de prestatieverminderende invloed van geneesmiddelen op rijvaardigheid. In deze figuur zijn de prestatieverminderende effecten van slaapmiddelen op het koershouden op de rechte weg uitgezet, gerangschikt naar ernst van de beïnvloeding.

De figuur is tot stand gekomen door bundeling van bijna 25 jaar slaapmiddelenonderzoek begonnen door Jim O'Hanlon (10), maar meer recentelijk voortgezet door Annemiek Vermeeren (11).

Wat erin te zien is, is een grote variëteit aan ernst van prestatieverminderingen, van afwezig tot zeer groot. Deze zijn voornamelijk toe te schrijven aan verschillen in dosering, en snelheid van absorptie en eliminatie. De middelen met langere eliminatie-halfwaardetijd, werken veel langer dan voor slaap noodzakelijk is en derhalve is gebruik van dat soort middelen onverenigbaar met verkeersdeelname. Ook is in de figuur af te lezen dat de nawerkingen van slaapmiddelen onder vergelijkbare experimentele omstandigheden aanmerkelijk groter kunnen zijn dan die van de alcohol limiet.

Bijwerkingen van medicijnen op het veilig kunnen besturen van voertuigen zijn dus voorspelbaar en hangen oa. af van het type receptor of enzym waar ze aan binden in de hersenen, de dosis, de werkingsduur, het tijdstip van inname en de gebruiksduur van het betreffende middel.

Er zijn later overigens nog meer testvormen met de geïnstrumenteerde auto ontwikkeld en met succes toegepast zoals het meten van volggedrag, afstand houden en rem-reactietijd, het meten van aandacht en kijkgedrag; en gedragsobservatie tijdens het rijden in de stad.

Medio 1997 dreigden die methoden voor Maastricht verloren te gaan 
omdat de opheffing van het IHP aangekondigd werd. Inmiddels werkten een aantal voormalige medewerkers daarvan waaronder Eric Vuurman en ikzelf al enkele jaren bij Psychiatrie \& Neuropsychologie onder de bezielende leiding van Prof. Jolles. Jan Ramaekers en Annemiek Vermeeren gingen toen full-time over naar de Faculteit Psychologie. Op uitdrukkelijk en unaniem verzoek van deze genoemde mensen en na indringende gesprekken met het College van Bestuur is toen besloten de noodzakelijke maatregelen te treffen om het specifieke Drugs \& Driving onderzoek te behouden.

Omdat er onderzoeken in portefeuille waren is er misschien niet een vliegende maar wel een rijdende doorstart gemaakt. Vanaf 1998 waren dus de onderzoeksactiviteiten van een aantal voormalige IHP medewerkers weer verenigd binnen het onderzoeksinstituut Hersenen \& Gedrag. Wel was het nu niet meer een klein zelfstandig instituut, maar een onderzoekslijn binnen één van de drie divisies in een groot onderzoeksinstituut.

Een andere manier om de geschetste ontwikkelingen te bekijken is om het verloop van de psychofarmacologie personeelssterkte over de jaren te beschouwen.

Het IHP bestond alleen gedurende de eerste 3 jaar deels uit 4 fte uit de eerste geldstroom en bestond daarna alleen maar uit ze geldstroom formatie, opgebracht uit onderzoekscontracten.

Vanaf 1992 is ook de formatie die zich bezighield met experimenteel psychofarmacologisch onderzoek bij de Neuropsychologie groep van Prof. Jolles, waartoe ik ook zelf behoorde, in kaart gebracht. Vanaf 1998 is door de sluiting van het IHP de gehele onderzoekscapaciteit ondergebracht bij Hersenen \& Gedrag. Het onderwijs is voornamelijk bij de Faculteit Psychologie ondergebracht, en een klein deel bij de Faculteit Geneeskunde.

Goed is te zien dat de psychofarmacologie-activiteit bij Neuropsychologie zich al aan het vergroten was terwijl het IHP in volume afnam. Het lijkt misschien alsof hier een samenhang is, maar het psychofarmacologisch onderzoek bij Neuropsychologie richtte zich op ander onderzoek. Dit betrof de vraag of leeftijdsgerelateerde achteruitgang van cognitieve functies zoals geheugen bij oudere mensen, maar ook bij dementie-patiënten voorkomen cq. bestreden kon worden met psychofarmaca. Het klinisch psychofarmacologisch onderzoek hiervan werd en wordt geleid 
door Prof. Frans Verhey, terwijl wij ons meer concentreerden op de vraag of je zoiets ook in experimentele vorm bij gezonde jongeren kon bestuderen, bijvoorbeeld wanneer ze vergeetachtig werden gemaakt door ze zuurstofarme lucht te laten ademen tijdens het verrichten van cognitieve taken.

Er is een theorie waarin verondersteld wordt dat één van de oorzaken van verminderde cognitieve prestatie bij ouderdom is dat er minder zuurstof beschikbaar is in de hersenen. Je kunt dit natuurlijk ook bereiken door proefpersonen plotseling met een helicopter naar grote hoogte te transporteren en kijken wat dat voor invloed op aandacht en geheugen heeft, iets wat ze in Zwitserland wel eens geprobeerd hebben. Eenvoudiger is het om proefpersonen zuurstofarme lucht laten ademen. Dat is nou een voorbeeld van een model van cognitieve dysfunctie, of vergeetachtigheid. Een model hoort bij een theorie en levert het protocol om een toetsbaar experiment op te zetten. Het waren dit soort modellen waar we bij Neuropsychologie ons gedurende enige jaren op geconcentreerd hebben getuige de promotieonderzoeken van Eef Hogervorst, Tineke Klaassen, Jeroen Schmitt, Sjacko Sobczak en Brenda Jorissen.

Dit hypoxie-model is misschien wel het beste voorbeeld van een biologische manipulatie. De meeste andere modellen die we gebruikten gaan uit van een farmacologische manipulatie. Zoals bijvoorbeeld het scopolamine model, het tryptofaan-depletie model en het eerder geillustreerde serotonine provocatie-model. Al deze modellen gaan over deeltheorieën van de chemie of de neurofarmacologie van cognitief en emotioneel functioneren. Ze houden zich bezig met de vraag hoe onze waarnemings, gevoels-, herinnerings-, handelings- en denkprocessen chemisch werken. Er worden steeds nieuwe stoffen en nieuwe receptoren beschreven, dus voorlopig zullen we er ook nog niet mee klaar zijn.

Niet alleen wijzelf, maar vooral onze omgeving voelt de behoefte om onze inspanningen zichtbaar te maken en in getallen uit te drukken. De publicaties in de zgn. wetenschappelijke tijdschriften met impactfactor zijn vanaf 1998 geteld en vergeleken met de zeer recent door Hersenen \& Gedrag ingestelde hoge norm van 6 publicaties per volle onderzoeks fte per jaar. Wij zitten daar al geruime tijd overheen, dan wel net tegenaan. Ik ben ervan overtuigd dat, nu we deze norm eenmaal kennen, het niet moeilijk is om daar in de toekomst altijd aan te voldoen.

Een snelle telling leert dat er vanuit de psychofarmacologie de afgelopen 
11 jaar 11 proefschriften aan deze universiteit het licht hebben gezien. Vijf daarvan waren formeel gedefinieerde AlO plaatsen die ofwel geheel of gedeeltelijk onder onze leiding stonden en de gemiddelde tijd totaan de oplevering van het proefschrift was 4.5 jaar. Dit steekt gunstig af tegen het universitaire gemiddelde. Met de constatering dat we al geruime tijd steeds 4 AlO plaatsen in de psychofarmacologie hebben, is de voorspelling dat we de komende jaren minstens éen keer per jaar een feestje hebben vrijwel risicoloos. En ik wil daarbij nog wel even benadrukken dat dat dus ook betekent dat ik daarmee het volste vertrouwen uitspreek in de zittende AIO's Eef Theunissen, Kim Kuypers, Marleen Wingen en Linda Jans. Want ik weet dat de eerste 3 die al een tijdje bezig zijn, over veel recente onderzoeksresultaten beschikken die zeer de moeite waard zijn om gepubliceerd te worden.

\section{Toekomstperspectief}

De geschetste identiteit van de experimentele psychofarmacologie is door de jaren heen enerzijds gelijk gebleven: drugs and driving is nu eenmaal een duidelijke blikvanger. Anderzijds is de identiteit echter ook ver" der ontwikkeld en uitgebreid met Neuropsychologische-, Biologisch Psychiatrische- en Voedings-invloeden. Er is een zeer actieve werkgroep Experimentele Psychofarmacologie en ook nog een specifieke serotonine-werkgroep die de interesse trekt van veel medewerkers en studenten uit de faculteiten Geneeskunde, Gezondheidswetenschappen en Psychologie.

De toekomst van dit multidisciplinaire vakgebied hangt behalve van onszelf, m.i. ook af van de partners met wie en voor wie er gewerkt wordt.

Misschien is het opmerkelijk dat ik Onderwijs als partner bovenaan zet, omdat bijna mijn hele verhaal in het teken van onderzoek heeft gestaan. Ik ben echter van mening dat dat op dit moment onze allerhoogste prioriteit is. Onderzoek bestaat uit de vergaring van kennis en onderwijs bestaat uit de verspreiding en bestendiging ervan. Als zodanig zijn ze niet los van elkaar te zien. Psychofarmacologie vormt in ieder geval impliciet een centraal thema in het bachelor onderwijs in de Biologische Psychologie. Belangrijk onderwijs houdt ook stages, AlO-promotie onderzoek en internationale uitwisselingsprogramma's in, zoals die met groot succes door Prof. Steinbusch onder het Europese Marie-Curie programma zijn geïnitieerd.

Dit is allemaal zo belangrijk omdat we ons moeten realiseren dat we met 
deze groep een uniek stukje kennis vertegenwoordigen dat niet uit zichzelf behouden zal blijven. Het verleden heeft dat wel geleerd. Die kennis, die perfect past in de Faculteit Psychologie, het Instituut Hersenen \& Gedrag, in de onderzoeksschool EURON en belangrijk is voor de Biologische en Cognitieve Psychologie, moet dus worden doorgegeven aan volgende generaties. En onderwijs en alle activiteiten die met verspreiding van kennis verwant zijn, staan dan voorop.

De ze geldstroom projecten die oa. door NWO worden gehonoreerd zijn in onze groep wat ondervertegenwoordigd. Om die reden is en blijft dit een punt van aandacht. We hebben, met Prof. Eric Postma en Arjan Blokland hoge ogen gegooid dit jaar met een aanvraag naar de modellering van neurochemie van geheugen met behulp van kunstmatige intelligentie. Maar we hebben meer onderwerpen in huis die zich uitermate goed lenen voor fundamenteel onderzoek. Dat sederende middelen psychologische functies vertragen en verslechteren en dus het rijgedrag beinvloeden is relatief makkelijk te meten. Maar waarom zijn stimulerende farmaca ook gevaarlijk? We hebben nu oa. met het onderzoek van Caroline Lamers bewezen dat we tegelijkertijd kunnen meten dat stoffen zoals ecstasy lager in de hersenen geregelde functies zoals stuurvardigheid verbeteren, terwijl ze hogere functies zoals inschatten van bewegingen, juist verslechteren (12). Ook het vervolgonderzoek laat zien dat we deze dissociaties tussen bottom-up en top-down processen kunnen meten. Dat zijn enorme uitdagingen om hier meer fundamenteel onderzoek aan vast te knopen.

Wat betreft de derde geldstroom zijn en blijven farmaceutische industrieën en voedingsindustrieën belangrijke partners. Ten eerste omdat vanuit die bedrijven concrete vraagstellingen komen naar de bijwerkingen van bestaande en nieuwe geneesmiddelen. Het doel is duidelijkere patiëntinformatie mbt. gebruik bij verkeersdeelname.

Daarnaast is er in de farmaceutische industrie een grote interesse om methoden en humane modellen te ontwikkelen waarmee van nieuwe potentiële geneesmiddelen, in een vroeg stadium voorspeld kan worden of ze inderdaad gaan doen wat de in vitro neurochemische- en dierproeven voorspellen. Deze activiteit kan ook gekenschetst worden als de methodologie van onderzoek naar psychofarmaca bij mensen. En dat is tevens het speerpunt van mijn bijzondere leeropdracht in de Experimentele Psychofarmacologie.

Ik kan de kern van deze leeropdracht in één one-liner samenvatten en die is: 'hoe meet je de normalisering of abnormalisering van gedrag die met 
behulp van psychofarmaca kan worden bereikt?'. Uiteraard veronderstelt dit een arsenaal van kennis over gedrag die deze vraag overstijgt: hoe meten we uberhaupt een gedragsverandering als gevolg van een experimentele of klinische behandeling? De behoefte aan kennis over het meten van gedrag is groot in de farmaceutische industrie. Alleen al de Research \& Development afdeling binnen het bedrijf waaraan ik tevens verbonden ben, GlaxoSmithKline, bestaat wereldwijd uit ongeveer 15000 medewerkers. Een belangrijk deel daarvan houdt zich bezig met geneesmiddelenontwikkeling voor Neurologische en Psychiatrische ziekten. Hier is dus sprake van een potentieel groot afzetgebied van wetenschappelijke kennis over hersenen \& gedrag, biologische psychologie, neurocognitie en neuroimaging, waarin totnutoe nauwelijks psychologen werkzaam zijn. Tevens betekent dit dat er voor studenten die zich in de psychofarmacologie willen bekwamen op ruime schaal emplooi is.

Met de 4e geldstroom wordt wel de overheidsinstanties bedoeld die maatschappelijke vragen beantwoord willen zien, zoals bijvoorbeeld hoe gevaarlijk het is om te rijden onder invloed van drugs zoals alcohol, marihuana en ecstasy. Daarnaast is er de vraag kunnen we dat, evt. analoog aan de adem-analyse van alcohol, langs de weg meten?

Veelbelovend is ook onze deelname aan een groot Europees project met 11 andere partners uit 7 landen, luisterend naar de naam IMMORTAL wat staat voor 'Impaired Motorists, Methods Of Roadside Testing and Assessment for Licensing'. Binnen dit meerjarig project wordt onderzoek gedaan naar de invloed van psychische ziekten, geneesmiddelen en drugs op rijvaardigheid. De experimentele psychofarmacologie groep uit Maastricht is naast de Universiteit van Leeds de belangrijkste partner in dit Europese project. 


\section{Dankwoord}

Tot slot wil ik dank uitspreken aan hen die het mogelijk gemaakt hebben dat ik hier nu sta. In zeer ruime zin betreft dat uiteraard in de eerste plaats mijn ouders en familie die mij altijd stimuleerden tot ontplooiing. Ik denk nu even met name aan mijn vader en mijn tante Anneke die er helaas niet meer zijn. Of het nu genetisch of omgevingsbepaald is weet ik niet, maar de neiging tot publiceren zit zeker in de familie: mijn moeder van 85 jaar heeft bijvoorbeeld vorig jaar nog een boekje uitgegeven met gedichten van 1945 tot nu (13).

In het bijzonder wil ik het bestuur en de commissie van Toezicht van de stichting wetenschapsbeoefening Limburg bedanken voor het ondersteunen van deze bijzondere leerstoel. Ik wil met name Prof. Harald Merckelbach, Prof. Gerjo Kok en Directeur Ed Sprokkel van de Faculteit Psychologie noemen voor hun actieve rol in deze. Dank gaat ook uit naar de Psychiatrie en Neuropsychologie in de personen van Prof. Jim van Os en Prof. Jelle Jolles. Dank gaat ook uit naar John Brown van GlaxoSmithKline die deze vorm van academisch-industriële interactie niet allen toestaat, maar ook sterk stimuleert.

De meeste mensen van de Experimentele Psychofarmacologie Groep heb ik al genoemd, behalve Anita van Oers en Cees van Leeuwen. Tenslotte, de veiligheidsklep op alle Maastrichtse rijvaardigheidsonderzoek is de rijschool van Henk en Irma Brauers, al sinds 1986 zijn zij de garantie dat al onze gedrogeerde proefpersonen zich altijd als een heer in het verkeer zullen blijven gedragen.

Ik heb gezegd. 


\section{Referenties}

1. E. C. Azmitia, Brain Research Bulletin 56,413-24 (Nov 15, 2001).

2. P. A. Vroon, Bewustzijn, Hersenen en Gedrag (Ambo, Baarn, 1975).

3. S. Schachter, J. E. Singer, Psychological Review 69, 379-99 (Sep, 1962).

4. H. M. Van Praag et al., Ann N Y Acad Sci 600, 501-10 (1990).

5. W. J. Riedel et al., Neuropsychopharmacology 26, 358-367 (2002).

6. S. M. Stahl, Essential Psychopharmacology. Neuroscientific Basis and Practical Applications (University Press, Cambridge, ed. 2nd, 2000).

7. J. F. O'Hanlon, T.W. Haak, G. J. Blaauw, J. B. Riemersma, Science 217, 79-81 (1982).

8. J. J. De Gier, Geneesmiddelen en Verkeersveiligheid (Elinkwijk, Utrecht, 1980).

9. J. F. O'Hanlon, J. J. De Gier, Eds., Drugs and Driving (Taylor and Francis, London, 1986).

10.J. F. O'Hanlon, E. R. Volkerts, Acta Psychiatr Scand 74, S95-104 (1986).

11. A. Vermeeren, J. Ramaekers, E. Vuurman, W. Riedel, Psychopraxis 2, 216224 (2000).

12. C. Lamers et al., Journal of Psychopharmacology 17, 379-387 (2003).

13. M. Hof, Het grote toverwoord (ISBN 90.71809.676; Boomker \& Savenije, Haren, 2003). 